\title{
Report from the CVOT Summit 2020: new cardiovascular and renal outcomes
}

\author{
Oliver Schnell ${ }^{1 *}$ (D, Xavier Cos $^{2}$, Francesco Cosentino ${ }^{3}$, Thomas Forst ${ }^{4}$, Francesco Giorgino ${ }^{5}$, \\ Hiddo J. L. Heersprink ${ }^{6}$, Mikhail Kosiborod ${ }^{7}$, Christoph Wanner ${ }^{8}$ and Eberhard Standl ${ }^{1}$
}

\begin{abstract}
The 6th Cardiovascular Outcome Trial (CVOT) Summit "Cardiovascular and Renal Outcomes 2020" was the first to be held virtually on October 29-30, 2020. As in previous years, this summit served as reference meeting for in-depth discussions on the topic of recently completed and presented major outcome trials. This year, focus was placed on the outcomes of VERTIS-CV, EMPEROR-Reduced, DAPA-CKD, and FIDELIO-DKD. Trial implications for diabetes management and the impact on new treatment algorithms were highlighted for diabetologists, cardiologists, endocrinologists, nephrologists, and general practitioners. Discussion evolved from major outcome trials using SGLT-2 inhibitors for treatment and prevention of heart failure and chronic kidney disease in people with and without diabetes, to additional therapy options for chronic kidney disease with a novel mineralocorticoid receptor antagonist. Furthermore, challenges in diabetes management like COVID-19 and obesity, as well as novel treatment strategies and guidelines, were discussed.

The 7th Cardiovascular Outcome Trial Summit will be held virtually on November, 18-19, 2021 (http://www.cvot.org).

Keywords: Diabetes, Cardiovascular disease, Heart failure, Chronic kidney disease, Obesity, VERTIS-CV, EMPERORReduced, DAPA-CKD, FIDELIO-DKD, SGLT2i inhibitor, GLP-1 receptor agonist, Mineralocorticoid receptor antagonist
\end{abstract}

\section{Background}

Diabetes mellitus is one of the fastest growing global health emergencies of the twenty-first century and has reached alarming levels. In the last 20 years, the estimated prevalence of diabetes (type 1 and type 2 combined) has risen from 151 million $(4.6 \%$ of the global population) in the year 2000, to 463 million (9.3\%) today [1]. By 2045, the International Diabetes Federation (IDF) estimates an increase in the number of people with diabetes to 700 million (10.9\%), with moderate increase in Europe (15\%) and North America (33\%) and high increase in South East Asia (74\%), the Middle East (96\%), and Africa (143\%) [2]. Furthermore, diabetes

\footnotetext{
*Correspondence: Oliver.Schnell@|rz.uni-muenchen.de

${ }^{1}$ Forschergruppe Diabetes e. V., Ingolstaedter Landstraße 1, 85764 Neuherberg (Munich), Germany

Full list of author information is available at the end of the article
}

affects especially low and middle income countries, as $77 \%$ of all people with diabetes worldwide live in those countries [3]. About $90 \%$ of the adults with type 2 diabetes mellitus (T2D) have at least one comorbid condition, each with their own risks and challenges. A recent systematic literature analysis, including over 4.5 million people with T2D, revealed that approximately $32 \%$ were affected by cardiovascular diseases (CVD). In detail, the study showed a prevalence of $\approx 29 \%$ for atherosclerosis, $\approx 21 \%$ for coronary heart disease, $\approx 15 \%$ for heart failure $(\mathrm{HF}), \approx 10 \%$ for myocardial infarction $(\mathrm{MI})$, and $\approx 7.5 \%$ for stroke [4]. Similarly, at least $40 \%$ of persons with T2D developed diabetic kidney disease (DKD) as leading cause of chronic kidney disease (CKD) and end-stage kidney disease (ESKD) [5]. CVD, CKD, and diabetes represent leading global causes of death, showing more than $25 \%$ increase for CVD associated deaths and nearly twofold increase for CKD and diabetes associated deaths

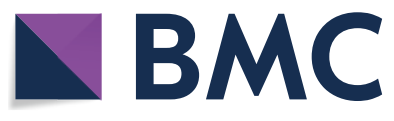

(c) The Author(s) 2021, corrected publication 2021. This article is licensed under a Creative Commons Attribution 4.0 International License, which permits use, sharing, adaptation, distribution and reproduction in any medium or format, as long as you give appropriate credit to the original author(s) and the source, provide a link to the Creative Commons licence, and indicate if changes were made. The images or other third party material in this article are included in the article's Creative Commons licence, unless indicated otherwise in a credit line to the material. If material is not included in the article's Creative Commons licence and your intended use is not permitted by statutory regulation or exceeds the permitted use, you will need to obtain permission directly from the copyright holder. To view a copy of this licence, visit http://creativecommons.org/licenses/by/4.0/. The Creative Commons Public Domain Dedication waiver (http://creativeco mmons.org/publicdomain/zero/1.0/) applies to the data made available in this article, unless otherwise stated in a credit line to the data. 
since 1990. T2D results in a reduced life expectancy by 10 years with CVD and by 16 years with CKD, the latter being the most prominent comorbidity in T2D [6].

Rising concerns of potentially higher risk for cardiovascular $(\mathrm{CV})$ events associated with some glucose-lowering medications was one of the contributing factors for the guidance from the US Food and Drug Administration (FDA) on the assessment of the cardiovascular safety of newer glucose-lowering drugs in 2008 [7]. As the result, a number of novel agents were evaluated in long-term cardiovascular outcome trials (CVOTs). Several major outcome trials for three glucose-lowering classes have been conducted for people with T2D: glucagon-like peptide-1 (GLP-1) receptor agonists, dipeptidyl peptidase-4 (DPP-4) inhibitors, and sodium-glucose cotransporter-2 (SGLT2) inhibitors. These major outcome trials included 17 CVOTs up to and including 2019: seven trials of GLP-1 receptor agonists [8-14], five trials of DPP-4 inhibitors [15-19], four trials of SGLT2 inhibitors [20-24] with an additional SGLT2 inhibitor trial for HF [25]. Furthermore, some of these trials also published data on kidney outcomes, although these were secondary endpoints or exploratory analyses. An exception was the CREDENCE trial published in 2019, which was designed with kidney outcomes as its primary endpoint [26].

Kidney function is typically evaluated by estimation of glomerular filtration rate (eGFR) based on serum creatinine measurement. Kidney damage is analysed by urine albumin-to-creatinine ratio (UACR) determination in a morning sample [27].

Outcome trials with GLP-1 receptor agonists demonstrated beneficial effects on albuminuria, while SGLT2 inhibitors showed a reduction in both albuminuria and "hard" kidney outcomes. As a trial primarily powered for kidney outcomes in patients with T2D and established DKD, CREDENCE showed positive effects for the SGLT2 inhibitor canagliflozin on such outcomes [26].

In 2020, the list of SGLT2 inhibitor major outcome trials in diabetes was expanded by two CVOTs (VERTISCV [23]-Ertugliflozin and SCORED [28]-Sotagliflozin), one renal outcome trial (DAPA-CKD [29]-Dapagliflozin), and two heart failure trials (EMPEROR-Reduced [30]- Empagliflozin and SOLOIST-WHF [31]-Sotagliflozin). In addition, a trial of a novel mineralocorticoid receptor antagonist (MRA) for renal outcomes (FIDELIO-DKD [32]-Finerenone) was published.

As in previous years [33-37], we present and summarise key aspects discussed at the sixth edition of the CVOT Summit in October 2020, which was the first to be held virtually. The CVOT Summit-Cardiovascular and Renal Outcomes 2020 was an interdisciplinary platform, which was also organized in conjunction with four study groups: Primary Care Diabetes Europe (PCDE, www.pcdeurope.org), European Diabetic Nephropathy Study Group (EDNSG, www.ednsg.org), the Incretin Study Group (www.easd-incretin.ku.dk), and the Working Group Diabetes \& Herz (www.ddg.org). Participants from five continents with specialities in diabetology, endocrinology, cardiology, nephrology, and primary care contributed to the discussions of the Virtual CVOT Summit on Cardiovascular and Renal Outcomes 2020 (www. cvot.org).

\section{Updates on CVOTs}

A summary of characteristics and results of kidney, HF and CV outcome trials published in 2020 is listed in Tables 1, 2, 3, 4.

\section{SGLT2 inhibitors}

\section{VERTIS-CV (Table 2: cardiovascular outcomes)}

The VERTIS-CV trial [23] investigated effects of ertugliflozin ( $5 \mathrm{mg}$ or $15 \mathrm{mg} /$ daily) in 8246 patients ( $\geq 40$ years old) with T2D and established atherosclerotic cardiovascular disease (ASCVD) with a mean follow-up time of 3.5 years. The primary endpoint (non-inferiority) was a composite outcome of major adverse cardiovascular events (MACE) comprising CV death, nonfatal MI, and nonfatal stroke (3P-MACE). The key secondary endpoints (superiority) were (a.) composite outcome of $\mathrm{CV}$ death/ hospitalization for heart failure (HHF), (b.) CV death, and (c.) kidney composite outcome (renal death, ESKD-dialysis/transplant, doubling of serum creatinine) [23].

Ertugliflozin achieved its primary endpoint, affirming non-inferiority for MACE (HR 0.97 [95.6\% CI 0.85-1.11]; $\mathrm{p}<0.001)$ over placebo. The key secondary composite endpoint of CV death or HHF did not differ significantly between groups (HR 0.88 [95.8\% CI 0.75-1.03]; $\mathrm{p}=0.11$ for superiority), nor did CV death (HR 0.92 [95.8\% CI $0.77-1.11$ ]; $p=0.39$ ), but a $30 \%$ lower risk of HHF was observed with ertugliflozin (HR 0.70 [95.8\% CI $0.54-$ $0.90] ; \mathrm{p}=0.006$ ). The kidney composite outcome was $19 \%$ lower, yet not statistically significant (HR 0.81 [95.8\% CI 0.63-1.04]; $\mathrm{p}=0.08$ ) [23]. A pre-specified analysis showed that the subgroups of patients with the greatest reduction of HF-related events were those with an estimated glomerular filtration rate (eGFR) below $60 \mathrm{~mL} / \mathrm{min} / 1.73 \mathrm{~m}^{2}$ and those with micro- and macro-albuminuria [38].

In terms of adverse events, ertugliflozin was generally safe and well tolerated with known risks for the SGLT2 inhibitor class, including genital mycotic infections. Acute kidney injury, diabetic ketoacidosis (DKA) and amputation were balanced between the groups[23]. 


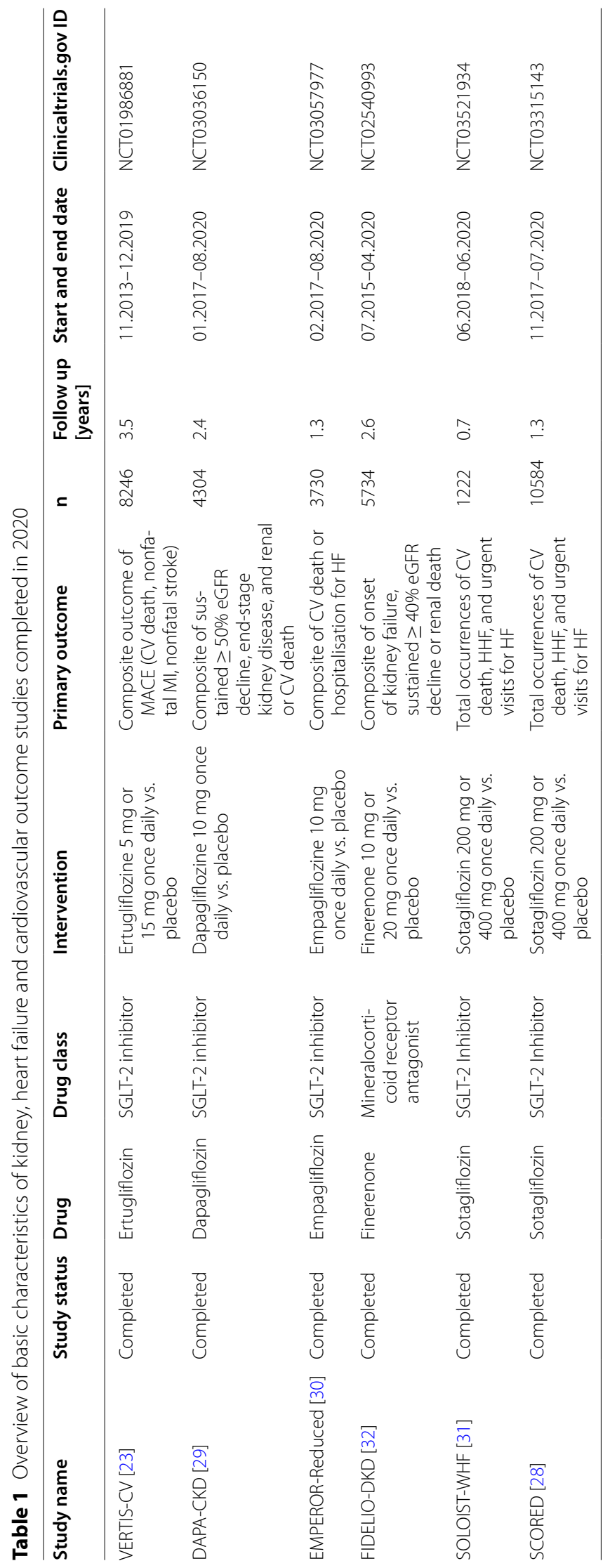


Table 2 Cardiovascular outcome trials completed in 2020: comparison of active vs. placebo group

\begin{tabular}{|c|c|c|c|}
\hline \multicolumn{2}{|l|}{ VERTIS-CV [23] } & \multicolumn{2}{|l|}{ SCORED [28] } \\
\hline Class \& cardiovascular outcomes & HR $(95.6 \% \mathrm{Cl}) \mathrm{p}$-value & Class \& cardiovascular outcomes & HR $(95.6 \% \mathrm{Cl}) \mathrm{p}$-value \\
\hline $\begin{array}{l}\text { Primary composite outcome } \\
\text { Composite outcome of MACE (CV } \\
\text { death, nonfatal MI, nonfatal stroke) }\end{array}$ & $\begin{array}{l}0.97(0.85-1.11) \\
p<0.001\end{array}$ & $\begin{array}{l}\text { Primary composite outcome } \\
\text { Total occurrences of } \mathrm{CV} \text { death, } \mathrm{HHF} \text {, } \\
\text { and urgent visits for HF }\end{array}$ & $\begin{array}{l}0.74(0.63-0.88) \\
p<0.001\end{array}$ \\
\hline $\begin{array}{l}\text { Secondary outcome } \\
\text { CV death or HHF }\end{array}$ & $\begin{array}{l}0.88(0.75-1.03) \\
p=0.11\end{array}$ & $\begin{array}{l}\text { Secondary outcome } \\
\text { Total occurrence of HF events }\end{array}$ & $\begin{array}{l}0.67(0.55-0.82) \\
p<0.001\end{array}$ \\
\hline $\begin{array}{l}\text { Secondary outcome } \\
\text { CV death }\end{array}$ & $\begin{array}{l}0.92(0.77-1.11) \\
p=0.39\end{array}$ & $\begin{array}{l}\text { Secondary outcome } \\
\text { CV death }\end{array}$ & $\begin{array}{l}0.90(0.73-1.12) \\
p=0.35\end{array}$ \\
\hline $\begin{array}{l}\text { Secondary outcome } \\
\text { Hospitalization for heart failure }\end{array}$ & $\begin{array}{l}0.70(0.54-0.90) \\
p=0.006\end{array}$ & $\begin{array}{l}\text { Secondary outcome } \\
\text { 3P-Mace and HHF events }\end{array}$ & $0.72(0.63-0.83)$ \\
\hline $\begin{array}{l}\text { Secondary outcome } \\
\text { Kidney composite: dialysis/transplant, } \\
\text { doubling of serum creatinine level, } \\
\text { or renal death }\end{array}$ & $\begin{array}{l}0.81(0.63-1.04) \\
p=0.08\end{array}$ & $\begin{array}{l}\text { Secondary outcome } \\
\text { All-cause mortality }\end{array}$ & $0.99(0.83-1.18)$ \\
\hline Adverse events & $\begin{array}{l}\text { Event rate (\%) active vs. placebo } \\
\text { group }\end{array}$ & Adverse events & $\begin{array}{l}\text { Event rate (\%) active vs. } \\
\text { placebo group }\end{array}$ \\
\hline Urinary tract infection & 12.2 vs. 12.0 vs. 10.2 & Diarrhea & 8.5 vs. 6.0 \\
\hline Acute pancreatitis & 0.4 vs. 0.2 vs. 0.4 & Genital infections & 2.4 vs. 0.9 \\
\hline Diabetic ketoacidosis & 0.3 vs. 0.4 vs. 0.1 & Diabetic ketoacidosis & 0.6 vs. 0.3 \\
\hline
\end{tabular}

\section{DAPA-CKD (Table 3: kidney outcomes)}

The DAPA-CKD trial [29] assessed whether treatment with dapagliflozin $(10 \mathrm{mg} /$ daily) reduces the risk of kidney and CV events in 4304 people with CKD, with or without T2D. Patients with CKD who had an eGFR $\geq 25$ to $\leq 75 \mathrm{~mL} / \mathrm{min} / 1.73 \mathrm{~m}^{2}$ and a $\mathrm{UACR} \geq 200$ to $\leq 5000 \mathrm{mg} / \mathrm{g}$ (22.6 to $564 \mathrm{mg} / \mathrm{mmol})$ were enrolled. In addition, all patients were maintained on a stable and individualized maximum tolerated dose of an angiotensin-converting-enzyme (ACE) inhibitor or angiotensinreceptor blocker (ARB) for at least 4 weeks. Two-third of participants had a diagnosis of T2D. The primary outcome was a composite of sustained $\geq 50 \%$ eGFR decline, ESKD, and renal or CV death. Secondary outcomes (in hierarchical order) encompassed (a.) a composite outcome of sustained $\geq 50 \%$ eGFR decline, ESKD or renal death, (b.) CV death or HHF, and (c.) all-cause mortality. The trial was stopped early for efficacy based on a recommendation from the independent Data Monitoring Committee following a regular review meeting [29].

During a median of 2.4 years follow-up, dapagliflozin significantly reduced the primary composite outcome by $39 \%$ (HR 0.61 [95\% CI $0.51-0.72]$; $\mathrm{p}<0.0001)$, with risk reduction for ESKD (HR 0.64 [95\% CI 0.50-0.82]; $\mathrm{p}<0.0004$ ), CV death (HR 0.81 [95\% CI $0.58-1.12$ ]; $\mathrm{p}<0.203$ ), and a sustained eGFR decline $\geq 50 \%$ (HR 0.53 [95\% CI 0.42-0.67]; $\mathrm{p}<0.0001)$ compared to placebo. Pre-specified subgroup analysis did not show differences for people with T2D (HR 0.64 [95\% CI 0.52-0.79]) versus people without T2D (HR 0.50 [95\% CI $0.35-0.72]$ ) $(\mathrm{p}=0.24$ for interaction). Significant improvement of secondary outcomes was also observed: the risk for $\mathrm{CV}$ death or HHF (HR 0.71 [95\% CI 0.55-0.92]; $\mathrm{p}=0.0089$ ) and all-cause mortality (HR 0.69 [95\% CI $0.53-0.88$ ]; $\mathrm{p}=0.0035$ ) were all significantly reduced by dapagliflozin [29].

No significant increase of adverse events of interest was observed in the dapagliflozin group compared with the placebo group. Notably, no diabetic ketoacidosis events were reported in patients assigned to dapagliflozin, and patients without diabetes did not experience any severe hypoglycaemic episodes [29].

\section{EMPEROR-Reduced (Table 4: HF outcome)}

The EMPEROR-reduced trial [30] assessed the effect of empagliflozin ( $10 \mathrm{mg} /$ daily) in 3730 patients with chronic symptomatic HF, reduced ejection fraction of $40 \%$ or less (HFrEF), and elevated natriuretic peptides, with a median follow-up of 1.33 years. Of the 3730 patients enrolled, $50 \%$ had T2D, 34\% had prediabetes $\left(\mathrm{HbA}_{1 \mathrm{c}} 5.7-6.4 \%\right)$, and $16 \%$ had normoglycemia $\left(\mathrm{HbA}_{1 \mathrm{c}}<5.7 \%\right)$ [39]. The primary endpoint was a composite of $\mathrm{CV}$ death or HHF, followed by the first secondary endpoint of the total (first and recurrent) HHF. The key second secondary endpoint was the slope of decline in eGFR over time [30].

Empagliflozin significantly decreased the risk of the primary composite outcome by $25 \%$ (HR 0.75 [95\% CI $0.65-0.86$ ]; $\mathrm{p}<0.001$ ), driven primarily by lower risk of HHF (HR 0.69 [95\% CI 0.59-0.81]), with no significant 
Table 3 Kidney outcome trials completed in 2020: comparison of active vs. placebo group

\begin{tabular}{|c|c|c|c|}
\hline \multicolumn{2}{|l|}{ DAPA-CKD [29] } & \multicolumn{2}{|l|}{ FIDELIO-DKD [32] } \\
\hline $\begin{array}{l}\text { Class \& cardiovascular/Kidney } \\
\text { outcomes }\end{array}$ & HR $(95.6 \% \mathrm{Cl}) \mathrm{p}$-value & $\begin{array}{l}\text { Class \& cardiovascular/Kidney } \\
\text { outcomes }\end{array}$ & HR $(95.6 \% \mathrm{Cl}) \mathrm{p}$-value \\
\hline $\begin{array}{l}\text { Primary composite outcome } \\
\text { Composite of sustained } \geq 50 \% \text { eGFR } \\
\text { decline, end-stage kidney disease, } \\
\text { and renal or CV death }\end{array}$ & $\begin{array}{l}0.61(0.51-0.72) \\
p=0.0000000028\end{array}$ & $\begin{array}{l}\text { Primary composite outcome } \\
\text { Composite of onset of kidney failure, } \\
\text { sustained } \geq 40 \% \text { eGFR decline or } \\
\text { renal death }\end{array}$ & $\begin{array}{l}0.82(0.73-0.93) \\
p=0.001\end{array}$ \\
\hline $\begin{array}{l}\text { Secondary outcome } \\
\text { Sustained } \geq 50 \% \text { eGFR decline, ESKD } \\
\text { or renal death }\end{array}$ & $\begin{array}{l}0.56(0.45-0.68) \\
p=0.0000000018\end{array}$ & $\begin{array}{l}\text { Secondary outcome } \\
\text { Composite of } \mathrm{CV} \text { death, nonfatal MI, } \\
\text { nonfatal stroke, and HHF }\end{array}$ & $\begin{array}{l}0.86(0.75-0.99) \\
p=0.03\end{array}$ \\
\hline $\begin{array}{l}\text { Secondary outcome } \\
\text { Chronic dialysis, kidney transplanta- } \\
\text { tion, renal death }\end{array}$ & $\begin{array}{l}0.66(0.49-0.90) \\
p=0.0072\end{array}$ & $\begin{array}{l}\text { Secondary outcome } \\
\text { All-cause mortality }\end{array}$ & $0.90(0.75-1.07)$ \\
\hline $\begin{array}{l}\text { Secondary outcome } \\
\mathrm{CV} \text { death or HHF }\end{array}$ & $\begin{array}{l}0.71(0.55-0.92) \\
p=0.0089\end{array}$ & $\begin{array}{l}\text { Secondary outcome } \\
\text { Hospitalisation for any cause }\end{array}$ & $0.95(0.88-1.02)$ \\
\hline $\begin{array}{l}\text { Secondary outcome } \\
\text { All-cause mortality }\end{array}$ & $\begin{array}{l}0.69(0.53-0.88) \\
p=0.0035\end{array}$ & & \\
\hline Adverse events & $\begin{array}{l}\text { Event rate (\%) active vs. placebo } \\
\text { group }\end{array}$ & Adverse events & $\begin{array}{l}\text { Event rate (\%) active vs. } \\
\text { placebo group }\end{array}$ \\
\hline Kidney event & 7.2 vs. 8.7 & Hypertension & 7.5 vs. 9.6 \\
\hline Diabetic ketoacidosis & 0.0 vs. 0.1 & Hyperkalaemia & 15.8 vs. 7.8 \\
\hline Volume depletion & 5.9 vs. 4.2 & Hypertension & 7.5 vs. 9.6 \\
\hline
\end{tabular}

Table 4 Heart failure outcome trials completed in 2020: comparison of active vs. placebo group

\begin{tabular}{|c|c|c|c|}
\hline \multicolumn{2}{|l|}{ EMPEROR-reduced [30] } & \multicolumn{2}{|l|}{ SOLOIST-WHF [31] } \\
\hline Class \& Cardiovascular outcomes & HR $(95.6 \% \mathrm{Cl}) \mathrm{p}$-value & Class \& Cardiovascular outcomes & HR $(95.6 \% \mathrm{Cl}) \mathrm{p}$-value \\
\hline $\begin{array}{l}\text { Primary composite outcome } \\
\text { Composite of CV death or hospitali- } \\
\text { sation for HF }\end{array}$ & $\begin{array}{l}0.75(0.65-0.86) \\
p<0.001\end{array}$ & $\begin{array}{l}\text { Primary composite outcome } \\
\text { Total occurrences of CV death, HHF, } \\
\text { and urgent visits for HF }\end{array}$ & $\begin{array}{l}0.67(0.52-0.85) \\
p<0.001\end{array}$ \\
\hline $\begin{array}{l}\text { Secondary outcome } \\
\text { Total no. of hospitalisations for HF }\end{array}$ & $\begin{array}{l}0.70(0.58-0.85) \\
p<0.001\end{array}$ & $\begin{array}{l}\text { Secondary outcome } \\
\text { Total occurrence of HF events }\end{array}$ & $\begin{array}{l}0.64(0.49-0.83) \\
p<0.001\end{array}$ \\
\hline $\begin{array}{l}\text { Secondary outcome } \\
\text { Mean slope of change in eGFR }-\mathrm{ml} / \\
\mathrm{min} / 1.73 \mathrm{~m}^{2} \text { per year }\end{array}$ & $\begin{array}{l}1.73(1.10-2.37) \\
p<0.001\end{array}$ & $\begin{array}{l}\text { Secondary outcome } \\
\mathrm{CV} \text { death }\end{array}$ & $\begin{array}{l}0.84(0.58-1.22) \\
p=0.36\end{array}$ \\
\hline $\begin{array}{l}\text { Other prespecified analyses } \\
\text { Composite kidney outcome }\end{array}$ & $0.50(0.32-0.77)$ & $\begin{array}{l}\text { Secondary outcome } \\
\text { 3P-Mace and HHF events }\end{array}$ & $0.72(0.56-0.92)$ \\
\hline $\begin{array}{l}\text { Other prespecified analyses } \\
\text { No. of hospitalisation for any cause }\end{array}$ & $0.85(0.75-0.95)$ & $\begin{array}{l}\text { Secondary outcome } \\
\text { All-cause mortality }\end{array}$ & $0.82(0.59-1.14)$ \\
\hline $\begin{array}{l}\text { Other prespecified analyses } \\
\text { All-cause death }\end{array}$ & $0.92(0.77-1.10)$ & & \\
\hline Adverse events & $\begin{array}{l}\text { Event rate (\%) active vs. placebo } \\
\text { group }\end{array}$ & Adverse events & $\begin{array}{l}\text { Event rate (\%) active vs. } \\
\text { placebo group }\end{array}$ \\
\hline Worsening renal function & 3.2 vs. 5.1 & Diarrhea & 6.1 vs. 3.4 \\
\hline Genital tract infections & 1.7 vs. 0.6 & Severe hypoglycaemia & 1.5 vs. 0.3 \\
\hline Hypotension & 9.4 vs. 8.7 & Hypotension & 6.0 vs. 4.6 \\
\hline
\end{tabular}

decrease in CV death (HR 0.92, 95\% CI 0.75-1.12). Subgroup analysis showed similar treatment benefits in people with diabetes (HR 0.72 [95\% CI 0.60-0.87]) and without diabetes (HR 0.78 [95\% CI $0.64-0.97]$ ), respectively, $P$-interaction $=0.57 \quad[39] . \quad$ Significant improvement was observed for the key secondary outcome of total HHF by $30 \%$ (HR 0.70 [95\% CI 0.58-0.85]; $\mathrm{p}<0.001)$. In addition, the second key secondary outcome 
showed a slower decline in eGFR with empagliflozin over the treatment period (by $1.7 \mathrm{ml} / \mathrm{min} / 1.73 \mathrm{~m}^{2}$ per year [95\% CI 1.1-2.4]; p <0.001) compared to placebo. Furthermore, $\mathrm{HbA}_{1 \mathrm{c}}$ did not change in patients without diabetes, and there was no increased risk of hypoglycaemic episodes or DKA with empagliflozin [30].

\section{EMPEROR-Reduced vs. DAPA-HF}

A comparable decrease in the risk of the composite endpoint of $\mathrm{CV}$ death or worsening $\mathrm{HF}$ was observed in the DAPA-HF trial [25] (HR 0.74 [95\% CI 0.65-0.85]; $\mathrm{p}<0.001$ ) and the EMPEROR-Reduced trial [30] (HR 0.75 [95\% CI 0.65-0.86]; $\mathrm{p}<0.001$ ). Both DAPA-HF (assessing dapagliflozin) and EMPEROR-Reduced (assessing empagliflozin) were combined in a meta-analysis [40] to assess the effects of SGLT2 inhibitors on CV outcomes in patients with HFrEF, with or without diabetes. EMPEROR-Reduced [30] was designed to study the same target population as DAPA-HF, but included individuals with lower ejection fraction and higher natriuretic peptide levels. The combination of 8374 patients from both trials in a meta-analysis showed a $13 \%$ reduction in allcause mortality (pooled HR 0.87 [95\% CI 0.77-0.98]; $\mathrm{p}=0.018), 14 \%$ reduction in $\mathrm{CV}$ death (HR $0.86[95 \%$ CI 0.76-0.98]; $\mathrm{p}=0.028$ ) [40], and $38 \%$ reduction of the composite kidney endpoint (HR 0.62 [95\% CI 0.43-0.90]; $\mathrm{p}=0.013$ ). Taken together, the combined results of DAPA-HF and EMPEROR-Reduced enrolled a broader spectrum of severity of HF than either trial alone. When data was combined from both trials, reduced risk of the composite endpoint of $\mathrm{CV}$ death or HHF and improved kidney outcomes were observed [40].

\section{SOLOIST-WHF (Table 4: HF outcomes) and SCORED (Table 2: cardiovascular outcomes)}

Two other SGLT2 inhibitor trials evaluated sotagliflozin, which also provides gastrointestinal SGLT1 inhibition, and were published shortly after the Virtual CVOT Summit 2020 [28, 31]. Both trials ended early due to loss of funding from the sponsor. This led to a reduction in power to test for the original primary endpoints. Due to these constraints, as well as evolution of the field since the trials were initiated, led to new primary composite endpoints being pre-specified in the statistical analysis plans prior to database lock. Furthermore, clinical events comprising the primary and secondary endpoints were reported by the site investigators, and not adjudicated.

The SOLOIST-WHF trial assessed the effect of a daily dose of $200 \mathrm{mg}$ sotagliflozin (with a dose increase to $400 \mathrm{mg}$, depending on tolerability) in 1222 patients with T2D who were either hospitalised for worsening HF or recently discharged, with a median follow-up time of
9 months. The trial was originally designed with a primary endpoint of the first occurrence of either death from CV causes or HHF. The new primary composite endpoint was the total number of deaths from $\mathrm{CV}$ causes, HHF and urgent visits for HF [31].

The primary composite outcome was significantly reduced with sotagliflozin versus placebo by $33 \%$ (HR 0.67 [95\% CI 0.52-0.85]; $\mathrm{p}<0.001$ ), with a relative risk reduction of CV death by $16 \%$ (HR 0.84 [95\% CI $0.58-$ 1.22]) and all-cause death by $18 \%$ (HR 0.82 [95\% CI $0.59-1.24]$ ). Of importance, there was similar treatment benefit in patients with both reduced (LVEF $<50 \%$ : HR 0.72 [95\% CI 0.56-0.94]) and preserved (LVEF > 50\%: HR 0.48 [95\% CI $0.27-0.86]$ ) ejection fraction. In terms of adverse events, patients with sotagliflozin showed higher prevalence for diarrhoea (6.1\% vs. $3.4 \%)$ and for severe hypoglycaemia $(1.5 \%$ vs. $0.3 \%)$ compared to placebo. There was no excess of DKA events with sotagliflozin versus placebo, despite the fact that this trial evaluated acutely hospitalized or recently discharged patients [31].

The SCORED trial investigated the effect of $200 \mathrm{mg}$ sotagliflozin once daily (with a dose increase to $400 \mathrm{mg}$, depending on tolerability) in 10,584 patients with T2D, CKD with or without albuminuria (eGFR 25 to $60 \mathrm{~mL} /$ $\mathrm{min} / 1.73 \mathrm{~m}^{2}$ ), and risk for CVD with a median follow-up time of 16 months. As already described for the SOLOIST-WHF trial, the originally specified primary endpoints in the SCORED trial (first occurrence of MACE and the first occurrence of death from $\mathrm{CV}$ causes or HHF) were changed prior to database lock. The new primary endpoint was the total number of deaths from $\mathrm{CV}$ causes, HHF and urgent visits for HF [28].

Sotagliflozin significantly reduced the primary endpoint by $26 \%$ (HR 0.74 [95\% CI 0.63-0.88]; P $<0.001$ ), driven primarily by HF events, with no independent reduction in CV death (HR 0.90 [95\% CI 0.73-1.12]; $\mathrm{P}=35$ ). Of importance, sotagliflozin also reduced the risk of the original primary endpoints of time to first MACE by $16 \%$ (HR 0.84 [95\% CI $0.72-0.99]$ ) and time to first CV death or HHF by $23 \%$ (HR 0.77 [95\% CI $0.66-0.91$ ]; $\mathrm{P}<0.001$ ). In terms of adverse events, diarrhoea, genital mycotic infections, volume depletion, and DKA occurred more often in patients receiving sotagliflozin [28].

\section{Mineralocorticoid receptor antagonists FIDELIO-DKD: (Table 3: kidney outcomes)}

The FIDELIO-DKD trial [32] assessed the kidney and CV efficacy and safety of finerenone compared with placebo in patients with T2D and CKD. Finerenone is a novel, third-generation, potent and selective oral, non-steroidal mineralocorticoid-receptor antagonist (MRA) that is associated with lower rates of hyperkalaemia and other 
typical MRA-associated side effects as compared with steroidal MRAs. MRAs such as spironolactone demonstrated some kidney protective effects, such as reduced albuminuria, and favourable cardiovascular effects in patients with T2D and HF. In comparison to steroidal MRAs, finerenone shows greater MR selectivity, and its non-steroidal structure allows the binding of the MR with high affinity, which mitigates against adverse events like gynecomastia [41, 42].

The FIDELIO-DKD trial included 5734 patients with T2D and CKD. Patients had to have persistently high albuminuria (UACR $\geq 30$ but $<300 \mathrm{mg} / \mathrm{g}$ ) with an eGFR $\geq 25$ to $\leq 60 \mathrm{ml} / \mathrm{min} / 1.73 \mathrm{~m}^{2}$, and history of diabetic retinopathy, or severe albuminuria (UACR $\geq 300$ but $<5000 \mathrm{mg} / \mathrm{g}$ ) and an eGFR $\geq 25$ to $\leq 75 \mathrm{ml} / \mathrm{min} / 1.73$ $\mathrm{m}^{2}$. All patients were treated with renin-angiotensin system blockade at the maximum tolerated dose. The mean follow-up time was 2.6 years. The primary endpoint was a composite of time to first occurrence of kidney failure, a sustained decrease of eGFR $\geq 40 \%$ from baseline, or death from renal causes. The key secondary composite outcome was 3P-MACE or HHF [32].

Finerenone showed a significantly decreased risk of the primary composite outcome by $18 \%$ (HR 0.82 [95\% CI $0.73-0.93] ; p=0.001$ ), which was generally consistent across the pre-specified subgroups. Significant reduction in the key secondary composite outcome (i.e., 3P-MACE or HHF) was also observed (HR 0.86 [95\% CI 0.75-0.99]; $\mathrm{p}=0.03$ ) with finerenone. Hyperkalemia-related adverse events (serum potassium level $>5.6 \mathrm{mmol} / \mathrm{l}$ ) were twice as frequent with finerenone $(18.3 \%)$ versus placebo (9.0\%). Furthermore, patients who received finerenone had a higher mean serum potassium level than those who received placebo with a maximal difference of $0.23 \mathrm{mmol} / \mathrm{l}[32]$.

\section{Key topics discussed during the 6th CVOT Summit Challenges in diabetes management-novel strategies and guidelines}

SGLT-2-Inhibitors: novel outcome studies and treatment options for diabetes, kidney disease and heart failure

$\mathrm{CV}$ disease, HF, and progression of kidney disease are the leading causes of morbidity and mortality in people with T2D. Several guidelines now recommend the use of SGLT2 inhibitors as first-line treatment in patients with established ASCVD, HF or DKD [43-45]. Effects of SGLT2 inhibitors on CV and kidney outcomes are largely consistent across the trials [20-26, 28-31], suggesting a class effect. The greatest, common benefits across all trials are the reduced risk of HHF $(\approx 25-30 \%)$ and kidney disease progression $(\approx 40 \%)$ [46]. These benefits are independent of baseline ASCVD, prior HF, and occur across a spectrum of baseline eGFR and albuminuria. Furthermore, comparable benefits of weight loss, reduction of blood pressure, and reduction of HbA1c can be found in the whole class of SGLT2 inhibitors [46]. In contrast to that, except for sotagliflozin, the MACE efficacy was generally modest across the class $(\approx 10 \%)$, and only the EMPA-REG outcome trial in T2D [20] and DAPA-HF trial in HF [22] found independently significant reductions in $\mathrm{CV}$ death. Furthermore, DAPA-CKD showed a considerable reduction in all-cause mortality among patients with CKD.

Despite the introduction of novel treatments such as SGLT2 inhibition, the residual risk of progression to ESKD remains substantial [47]. T2D accompanied with CKD is associated with tubulointerstitial fibrosis and inflammation, with a strong relationship between inflammatory cytokines (KRIS) in the kidney and the risk of ESKD [48]. Current treatment recommendations only address the management of haemodynamic and metabolic factors [49]. The use of drugs that block inflammation and fibrosis may be useful in reducing the risk of CKD progression, as the progression is driven by the combined effects of metabolic, haemodynamic, inflammatory, and fibrotic factors [50]. The novel non-steroidal MRA finerenone has a distinct mechanism of action, targeting inflammation and fibrosis. Together with SGLT2 inhibitors, finerenone could be potentially positioned as combination therapy for CKD, even though extensive data on this combined treatment approach is lacking at present [32].

\section{GLP-1 receptor agonists: an update}

To this date, 7 CVOTs with GLP-1RAs [8-14] have been published, and their evidence has been analysed by several meta-analyses [51-53]. The class of GLP-1 RAs differs in its structure and duration of action with inconsistent effects on cardiovascular outcomes. It is unclear whether differences in $\mathrm{HbA}_{1 \mathrm{C}}$, weight, hypoglycaemia or other factors such as potency, duration of action, or human GLP versus exendin based GLP may contribute to the observed heterogeneous results among the CVOTs. The group of Kristensen et al. [51], meta-analysing all 7 CVOTs using GLP-1 RAs [8-14], showed a significant $12 \%$ risk reduction for both MACE, as well as CV and all-cause mortality, a significant 9\% reduction in rates of $\mathrm{HHF}$, and a $17 \%$ significantly reduced risk for kidney outcomes driven by albuminuria. Unlike SGLT2i, benefit emerges after approximately 12 months, suggesting effects on vascular disease progression. These findings put forward a class effect of GLP-1 RAs with beneficial effects on atherosclerotic events, mortality, and kidney outcomes in patients with T2D.

\section{COVID-19}

The year 2020 was largely dominated by the spread of the new severe acute respiratory syndrome coronavirus 2 
(SARS-CoV-2). By the end of October 2020, the associated respiratory disease-coronavirus disease 2019 (COVID19)-has been diagnosed in more than 45 million individuals, resulting in more than 1.1 million deaths [54]. Infection and progression of COVID-19 is characterised by an initial infection phase, followed by a respiratory distress phase and a severe hyperinflammation state [55]. Besides the primary impact on the lungs, causing interstitial pneumonitis and severe acute respiratory distress syndrome (ARDS), COVID-19 also affects multiple other organs, especially the cardiovascular system and the kidneys [56]. Risk of severe infection and mortality is increased by comorbidities such as diabetes, obesity, CVD, hypertension, HF, chronic pulmonary disease, cancer, ESKD, organ transplantation and neurological diseases [57]. Suboptimal glucose control in patients with diabetes may be associated with higher risk of SARS-CoV-2 infection due to several mechanisms, such as increased expression of ACE2 [58]. Its expression by endothelial cells might empower Sars-CoV-2 to infect blood vessels by binding to the ACE2 receptor, which thus enhances the wide spread of the virus [59]. As a result, systemic inflammation and the so-called cytokine storm may damage organs such as the heart, liver, and kidneys [60, 61].

\section{CVOT results translated into Primary Care Diabetes} Guidelines and Recommendations

To assist primary care physicians, the Primary Care Diabetes Europe has formulated a position statement summarising the current understanding of the available T2D treatment options in various patient populations, especially patients with CVD $[62,63]$. The position statement is intended to be a practical counterpart to national and international management guidelines. The statement contains a series of presentations and discussions to identify the key issues in CVD risk management in patients with T2D. These patients are categorized into different risk groups based on individual factors such as ASCVD, HF, CKD, and obesity. Several pharmacotherapeutic agents such as metformin, SGLT2 inhibitors, GLP-1 RA, and DDP-4i are suggested for the different risk groups [62, 63].

Primary prevention of CVD in the light of current diabetes guidelines

The ADA and ESC/EASD guidelines underline that treatment targets should be individualised for each patient, by using a multifactorial treatment algorithm for management of complications such as ASCVD, HF, and CKD in T2D $[64,65]$. The ADA recommends five key targets that most adults with diabetes should achieve: 1) glycaemic control, 2) lifestyle modification (diet and exercise for weight management), 3) blood pressure control (ACE-I and ARB), 4) management of dyslipidaemia (statins intensified with ezetimibe), and 5) platelet inhibition (aspirin and other anti-thrombosis agents) [66]. In order to reach the $\mathrm{HbA}_{1 \mathrm{c}}$ targets, a high number of glucose-lowering medications is now available, which makes management of hyperglycaemia more complex. Agents such as GLP-1RA and SGLT2 inhibitors are the most prominent glucoselowering medications in the treatment algorithms for the reduction of MACE in people with T2D, particularly with known ASCVD. The REWIND trial demonstrated a $13 \%$ risk reduction of MACE for the GLP1RA dulaglutide in a population in which $68.5 \%(6793$ patients) did not have established CVD. [67]. Furthermore, the REWIND trial endorses findings from multiple trials supporting the benefit of GLP-1RA for MACE reduction [68]. Therefore, GLP-1RA should be preferably prescribed for patients with ASCVD or at high-risk for CVD, while SGLT2 inhibitors should be prioritised over GLP-1RA for patients with HF or CKD [44].

\section{The "living guideline" approach}

Clinicians and their patients need timely clinical practice guidelines. Guidelines depend on systematic reviews which are difficult to keep up-to-date as research evidence is emerging rapidly. Societies need to apply the best current standards, methods, processes, and platforms for their guidelines to be trustworthy, accessible, and understandable. In 2017, a novel approach termed "Living systematic review" (LSR) was developed. LSRs are reviews that are constantly updated as new evidence becomes available [69]. The advent of LSR enabled the concept of "living guidelines" (Fig. 1), with the possibility to provide timely, up-to-date, and high-quality guidance to clinicians and patients [70].

\section{Obesity—risk factor and treatment target}

Obesity is one of the major health burdens of the twentyfirst century reaching pandemic levels. Prevalence of obesity has tripled from 1975 to 2014, with a trend to reaching a global prevalence of $18 \%$ in men and surpass $21 \%$ in women by the year 2025 [71]. A high body-mass index (BMI) substantially increases the risk of diseases such as T2D, fatty liver disease, hypertension, ASCVD HFpEF, dementia, osteoarthritis, obstructive sleep apnoea, and several cancers [72]. Consequently, obesity contributes to a decline in both the quality of life and life expectancy. During the beginning of the COVID-19 pandemic, obesity as comorbidity appeared to be prominent in about $50 \%$ of the hospitalized patients infected with SARS-CoV-2 [73]. In these patients, the risk for hospitalisation, intensive care unit admission, invasive mechanical 


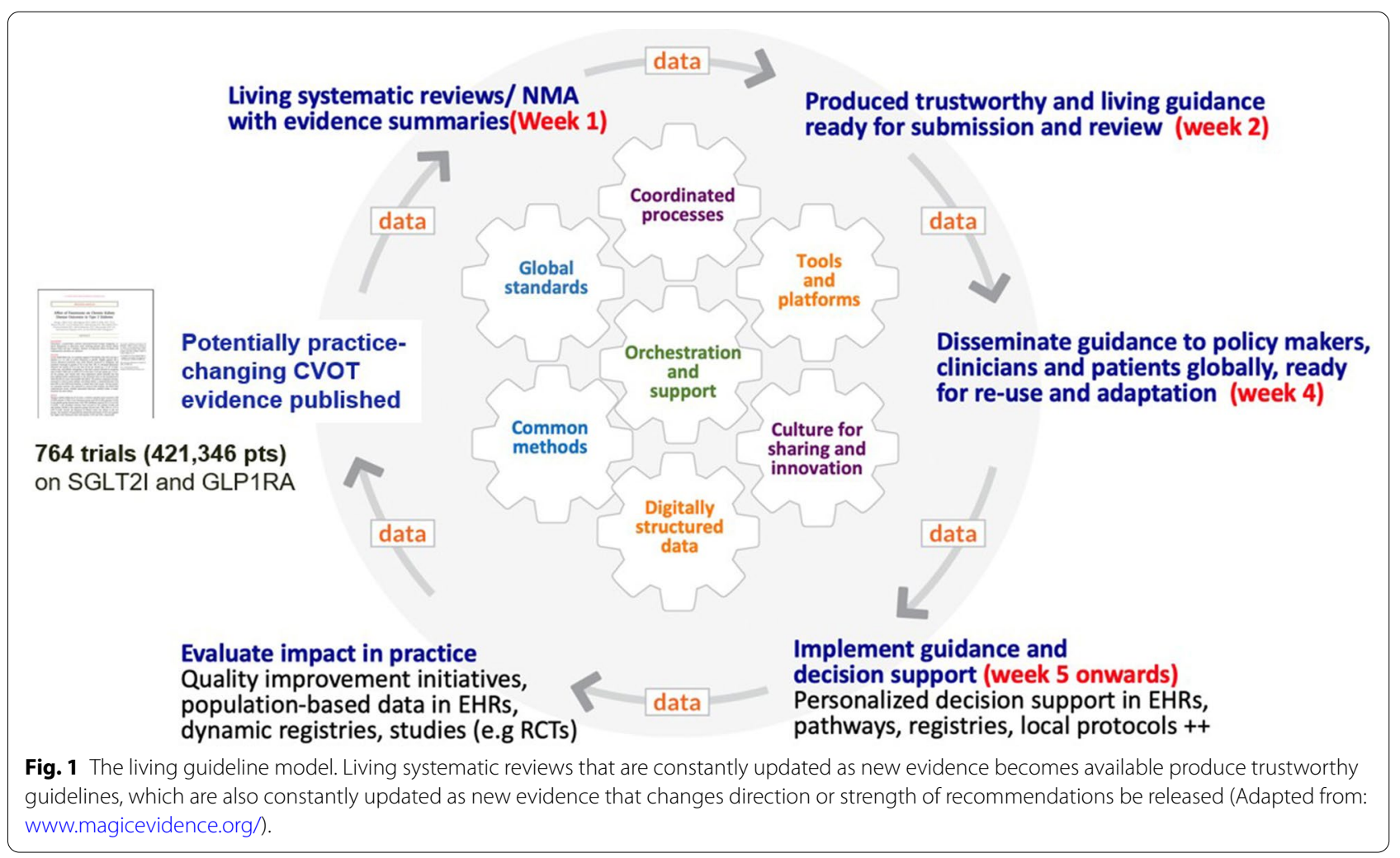

ventilation requirement, and mortality was increased [74]. The mechanisms causing obesity are not understood well enough to effectively prevent and treat the disease. Treatment is an intensifying lifelong multidisciplinary management with behaviour intervention, pharmacotherapy, and bariatric surgery $[75,76]$. Current pharmacological options for weight management in the US and Europe are: (1) the lipase inhibitor orlistat which reduces fat absorption from intestines, (2) the GLP-1RA liraglutide (up to $3.0 \mathrm{mg}$ daily) as appetite suppressor, and (3) the combination of the antidepressant bupropion and the opiate antagonist naltrexone as appetite suppressor [7779]. The ongoing Semaglutide Treatment Effect in People with obesity (STEP) program evaluates the efficacy and safety of the GLP-1RA semaglutide $2.4 \mathrm{mg}$ subcutaneously once weekly in a broad population. The program consists of 5 trials and provides insights on weight management in people with obesity with and without T2D. Early data from press suggests marked efficacy of semaglutide in reducing body weight [80].

\section{Cardiometabolic Center of Excellence}

Multiple guidelines started in collaboration between international professional groups adopt a selection of glucose-lowering agents based on risk, not just $\mathrm{HbA}_{1 \mathrm{c}}$ control, for T2D treatment [43-45]. Nonetheless, collaborative systems of care are mostly nascent, and the use of therapies with proven outcome benefits remains low $[81,82]$. As effective clinical care models have not yet been formed, the Saint Luke's Haverty Cardiometabolic Center of Excellence has been established in Kansas City to become a new model of care for patients with T2D and CVD, by creating a multi-disciplinary, team based, patient-centered approach to aggressive, comprehensive risk reduction. To maximize $\mathrm{CV}$ risk reduction and to reduce morbid events, there is a need for key competencies (standard protocols, patient and staff education) combined with comprehensive treatment plans and research initiatives. This approach may be an opportunity to optimize guidelines and to improve outcomes. The team at Saint Luke's has also created a national organization, Cardiometabolic Center Alliance (www.cardiometa bolicalliance.org) with the purpose of helping other healthcare organizations build their own cardiometabolic centers of excellence, with the ultimate goal of improving quality of care and outcomes in patients with T2D and cardiovascular disease nationwide.

\section{Conclusion}

The sixth edition of the CVOT Summit discussed key results of four recently completed and published major outcome trials in a virtual, interactive, multi-disciplinary format. The summit covered one CVOT (VERTIS-CV), 
two trials designed to evaluate specifically kidney outcomes (DAPA-CKD and FIDELIO-DKD) and one trial for HF outcomes (EMPEROR-Reduced). In addition, two more CVOTs (SOLOIST-WHF and SCORED) were added to the report, as they were published shortly after the summit was held. The summit provided novel data, insights, strategies, and guidelines for specialists and primary care for cardiovascular and kidney therapy algorithms in people with and without T2D. In-depth discussions and presentations of upcoming kidney and HF trials like FIGARO-DKD, EMPA-KIDNEY, DELIVER, and EMPEROR-Preserved will be resumed at the $7^{\text {th }}$ edition of the CVOT Summit, which will be held virtually on November 18-19, 2021 (https://www.cvot.org).

\section{Abbreviations}

3P(4P)-MACE: 3-Point (4-point) major adverse cardiovascular event; ACE: Angiotensin-converting-enzyme; ARB: Angiotensin-receptor blocker; ASCVD: Atherosclerotic cardiovascular disease; CKD: Chronic kidney disease; CVD: Cardiovascular disease; CV: Cardiovascular; CVOT: Cardiovascular outcome trial; EASD: Study Group; EDNSG: European Diabetic Nephropathy Study Group: DKD: Diabetic kidney disease; DM: Diabetes mellitus; DPP-4i: Dipeptidylpeptidase 4 inhibitor; EASD: European Association for the Study of Diabetes; ESC: European Society of Cardiology; ESKD: End-stage kidney disease; FDA: US Food and Drug Administration; (e)GFR: (Estimated) glomerular filtration rate; HF: Heart failure; HFpEF: Heart failure with preserved ejection fraction; HFrEF: Heart failure with reserved ejection fraction; HHF: Hospitalisation for heart failure; HR: Hazard ratio; IDF: International diabetes federation; GLP-1 RA: Glucagon-like peptide 1 receptor agonist; LVEF: Left ventricular ejection fraction; MI: Myocardial infarction; MRA: Mineralocorticoid receptor antagonist: PCDE: Primary Care Diabetes Europe; SGLT-2i: Sodium/glucose cotransporter 2 inhibitor;T2D: Type 2 diabetes mellitus; UACR: Urine albumin-to-creatinine ratio.

\section{Acknowledgements}

We would like to thank all speakers and participants of the 6th CVOT Summit for their active involvement in the scientific discussions leading to the present report. We also like to thank Martin Miszon, Sciarc $\mathrm{GmbH}$, for his editorial and writing support of the manuscript. Moreover, we want to acknowledge the industry for their support of the meeting.

\section{Authors' contributions}

OS, XC, TF, FG, HH, MK, CW and ES contributed to the discussion and content of the report. All authors read and approved the final manuscript.

\section{Funding}

No funding supported the generation of this manuscript.

\section{Availability of data and materials}

Data sharing not applicable to this article as no datasets were generated during the current study.

\section{Declarations}

Ethics approval and consent to participate Not applicable.

\section{Consent for publication}

Not applicable.

\section{Competing interests}

The authors declare that they have no competing interests.

\section{Author details}

${ }^{1}$ Forschergruppe Diabetes e. V., Ingolstaedter Landstraße 1, 85764 Neuherberg (Munich), Germany. ${ }^{2}$ Sant Marti de Provençals Primary Care Centres, Barcelona, Spain. ${ }^{3}$ Karolinska University Hospital, Solna, Stockholm, Sweden. ${ }^{4}$ CRS Clinical Research Services Mannheim GmbH, Mannheim, Germany. ${ }^{5}$ Department of Emergency and Organ Transplantation, University of Bari Aldo Moro, Bari, Italy. ${ }^{6}$ Department of Clinical Pharmacy and Pharmacology, University of Groningen, University Medical Center Groningen, Groningen, Netherlands. ${ }^{7}$ Cardiometabolic Center of Excellence, University of Missouri-Kansas City, Kansas, MO, USA. ${ }^{8}$ Universitätsklinikum Würzburg, Würzburg, Germany.

Received: 19 February 2021 Accepted: 26 February 2021

Published online: 31 March 2021

\section{References}

1. International Diabetes Federation. IDF diabetes Atlas. 9th ed. Belgium: International Diabetes Federation; 2019.

2. Saeedi P, Petersohn I, Salpea P, Malanda B, Karuranga S, Unwin N, Colagiuri S, Guariguata L, Motala AA, Ogurtsova K, et al. Global and regional diabetes prevalence estimates for 2019 and projections for 2030 and 2045: results from the International Diabetes Federation Diabetes Atlas, 9(th) edition. Diabetes Res Clin Pract. 2019;157:107843.

3. Stand E, Khunti K, Hansen TB, Schnell O. The global epidemics of diabetes in the 21st century: Current situation and perspectives. Eur J Prev Cardiol. 2019;26:7-14

4. Einarson TR, Acs A, Ludwig C, Panton UH. Prevalence of cardiovascular disease in type 2 diabetes: a systematic literature review of scientific evidence from across the world in 2007-2017. Cardiovasc Diabetol. 2018;17(1):83.

5. Alicic RZ, Rooney MT, Tuttle KR. Diabetic kidney disease: challenges, progress, and possibilities. Clin J Am Soc Nephrol. 2017;12(12):2032-45.

6. Wen CP, Chang CH, Tsai MK, Lee JH, Lu PJ, Tsai SP, Wen C, Chen CH, Kao CW, Tsao CK, et al. Diabetes with early kidney involvement may shorten life expectancy by 16 years. Kidney Int. 2017;92(2):388-96.

7. Guidance for industry diabetes mellitus - evaluating cardiovascular risk in new antidiabetic therapies to treat type 2 diabetes. In: Edited by FDA 2008. https://www.federalregister.gov/documents/2008/12/19/E830086/guidance-for-industry-on-diabetes-mellitus-evaluating-cardiovasc ular-risk-in-new-antidiabetic

8. Pfeffer MA, Claggett B, Diaz R, Dickstein K, Gerstein HC, Kober LV, Lawson FC, Ping L, Wei X, Lewis EF, et al. Lixisenatide in patients with type 2 diabetes and acute coronary syndrome. N Engl J Med. 2015;373(23):2247-57.

9. Marso SP, Daniels GH, Brown-Frandsen K, Kristensen P, Mann JF, Nauck MA, Nissen SE, Pocock S, Poulter NR, Ravn LS, et al. Liraglutide and cardiovascular outcomes in type 2 diabetes. N Engl J Med. 2016;375(4):311-22.

10. Marso SP, Bain SC, Consoli A, Eliaschewitz FG, Jodar E, Leiter LA, Lingvay I, Rosenstock J, Seufert J, Warren ML, et al. Semaglutide and cardiovascular outcomes in patients with type 2 diabetes. N Engl J Med. 2016;375(19):1834-44.

11. Holman RR, Bethel MA, Mentz RJ, Thompson VP, Lokhnygina Y, Buse JB, Chan JC, Choi J, Gustavson SM, lqbal N, et al. Effects of once-weekly exenatide on cardiovascular outcomes in type 2 diabetes. N Engl J Med. 2017;377(13):1228-39.

12. Hernandez AF, Green JB, Janmohamed S, D'Agostino RB Sr, Granger CB, Jones NP, Leiter LA, Rosenberg AE, Sigmon KN, Somerville MC, et al. Albiglutide and cardiovascular outcomes in patients with type 2 diabetes and cardiovascular disease (Harmony Outcomes): a double-blind, randomised placebo-controlled trial. Lancet. 2018;392(10157):1519-29.

13. Gerstein HC, Colhoun HM, Dagenais GR, Diaz R, Lakshmanan M, Pais P, Probstfield J, Riesmeyer JS, Riddle MC, Ryden L, et al. Dulaglutide and cardiovascular outcomes in type 2 diabetes (REWIND): a double-blind, randomised placebo-controlled trial. Lancet. 2019;394(10193):121-30.

14. Husain M, Birkenfeld AL, Donsmark M, Dungan K, Eliaschewitz FG, Franco DR, Jeppesen OK, Lingvay I, Mosenzon O, Pedersen SD, et al. Oral semaglutide and cardiovascular outcomes in patients with type 2 diabetes. N Engl J Med. 2019;381(9):841-51.

15. Scirica BM, Bhatt DL, Braunwald E, Steg PG, Davidson J, Hirshberg B, Ohman P, Frederich R, Wiviott SD, Hoffman EB, et al. Saxagliptin and 
cardiovascular outcomes in patients with type 2 diabetes mellitus. N Engl J Med. 2013;369(14):1317-26.

16. Green JB, Bethel MA, Armstrong PW, Buse JB, Engel SS, Garg J, Josse R, Kaufman KD, Koglin J, Korn S, et al. Effect of sitagliptin on cardiovascular outcomes in type 2 diabetes. N Engl J Med. 2015;373(3):232-42.

17. White WB, Cannon CP, Heller SR, Nissen SE, Bergenstal RM, Bakris GL, Perez AT, Fleck PR, Mehta CR, Kupfer S, et al. Alogliptin after acute coronary syndrome in patients with type 2 diabetes. N Engl J Med. 2013;369(14):1327-35.

18. Rosenstock J, Perkovic V, Johansen OE, Cooper ME, Kahn SE, Marx N, Alexander JH, Pencina M, Toto RD, Wanner C, et al. Effect of linagliptin vs placebo on major cardiovascular events in adults with type 2 diabetes and high cardiovascular and renal risk: the CARMELINA randomized clinical trial. JAMA. 2019;321(1):69-79.

19. Rosenstock J, Kahn SE, Johansen OE, Zinman B, Espeland MA, Woerle HJ, Pfarr E, Keller A, Mattheus M, Baanstra D, et al. Effect of linagliptin vs glimepiride on major adverse cardiovascular outcomes in patients with type 2 diabetes: the CAROLINA randomized clinical trial. JAMA. 2019;322(12):1155-66.

20. Zinman B, Wanner C, Lachin JM, Fitchett D, Bluhmki E, Hantel S, Mattheus M, Devins T, Johansen OE, Woerle HJ, et al. Empagliflozin, cardiovascular outcomes, and mortality in type 2 diabetes. N Engl J Med. 2015;373(22):2117-28

21. Neal B, Perkovic V, Mahaffey KW, de Zeeuw D, Fulcher G, Erondu N, Shaw W, Law G, Desai M, Matthews DR, et al. Canagliflozin and cardiovascular and renal events in type 2 diabetes. N Engl J Med. 2017;377(7):644-57.

22. Wiviott SD, Raz I, Bonaca MP, Mosenzon O, Kato ET, Cahn A, Silverman MG, Zelniker TA, Kuder JF, Murphy SA, et al. Dapagliflozin and cardiovascular outcomes in type 2 diabetes. N Engl J Med. 2019;380(4):347-57.

23. Cannon CP, Pratley R, Dagogo-Jack S, Mancuso J, Huyck S, Masiukiewicz U, Charbonnel B, Frederich R, Gallo S, Cosentino F, et al. Cardiovascular outcomes with ertugliflozin in type 2 diabetes. N Engl J Med. 2020. https:// doi.org/10.1056/NEJMoa2004967.

24. Perkovic V, Jardine MJ, Neal B, Bompoint S, Heerspink HJL, charytan DM, edwards $r$, agarwal $r$, bakris $g$, bull $s$, et al. canagliflozin and renal Outcomes in Type 2 Diabetes and Nephropathy. N Engl J Med. 2019:380(24):2295-306.

25. McMurray JJV, Solomon SD, Inzucchi SE, Kober L, Kosiborod MN, Martinez FA, Ponikowski P, Sabatine MS, Anand IS, Belohlavek J, et al. Dapagliflozin in patients with heart failure and reduced ejection fraction. N Engl I Med. 2019:381(21):1995-2008.

26. Mahaffey KW, Jardine MJ, Bompoint S, Cannon CP, Neal B, Heerspink HJL, Charytan DM, Edwards R, Agarwal R, Bakris G, et al. Canagliflozin and cardiovascular and renal outcomes in type 2 diabetes mellitus and chronic kidney disease in primary and secondary cardiovascular prevention groups. Circulation. 2019;140(9):739-50.

27. Tuttle KR, Bakris GL, Bilous RW, Chiang JL, de Boer IH, Goldstein-Fuchs J, Hirsch IB, Kalantar-Zadeh K, Narva AS, Navaneethan SD, et al. Diabetic kidney disease: a report from an ADA Consensus Conference. Am J Kidney Dis. 2014;64(4):510-33.

28. Bhatt DL, Szarek M, Pitt B, Cannon CP, Leiter LA, McGuire DK, Lewis JB, Riddle MC, Inzucchi SE, Kosiborod MN, et al. Sotagliflozin in patients with diabetes and chronic kidney disease. N Engl J Med. 2020;384:129-39.

29. Heerspink HJL, Stefánsson BV, Correa-Rotter R, Chertow GM, Greene T, Hou F-F, Mann JFE, McMurray JJV, Lindberg M, Rossing P, et al. Dapagliflozin in patients with chronic kidney disease. N Engl J Med. 2020;383:1436-46.

30. Packer M, Anker SD, Butler J, Filippatos G, Pocock SJ, Carson P, Januzzi J, Verma S, Tsutsui H, Brueckmann M, et al. Cardiovascular and renal outcomes with empagliflozin in heart failure. N Engl J Med. 2020;383:1413-24.

31. Bhatt DL, Szarek M, Steg PG, Cannon CP, Leiter LA, McGuire DK, Lewis JB, Riddle MC, Voors AA, Metra M, et al. Sotagliflozin in patients with diabetes and recent worsening heart failure. N Engl J Med. 2020;384:117-28.

32. Bakris GL, Agarwal R, Anker SD, Pitt B, Ruilope LM, Rossing P, Kolkhof $P$, Nowack C, Schloemer P, Joseph A, et al. Effect of finerenone on chronic kidney disease outcomes in type 2 diabetes. N Engl J Med. 2020;383:2219-29.

33. Schnell O, Standl E, Cos X, Heerspink HJL, Itzhak B, Lalic N, Nauck M, Ceriello A. Report from the 5 th cardiovascular outcome trial (CVOT) summit. Cardiovasc Diabetol. 2020;19(1):47.

34. Schnell O, Standl E, Catrinoiu D, Itzhak B, Lalic N, Rahelic D, Skrha J, Valensi P, Ceriello A. Report from the 4th Cardiovascular Outcome Trial (CVOT)
Summit of the Diabetes \& Cardiovascular Disease (D\&CVD) EASD Study Group. Cardiovasc Diabetol. 2019;18(1):30.

35. Schnell O, Standl E, Catrinoiu D, Genovese S, Lalic N, Lalic K, Skrha J, Valensi P, Ceriello A. Report from the 3rd Cardiovascular Outcome Trial (CVOT) Summit of the Diabetes \& Cardiovascular Disease (D\&CVD) EASD Study Group. Cardiovasc Diabetol. 2018;17(1):30.

36. Schnell O, Standl E, Catrinoiu D, Genovese S, Lalic N, Skra J, Valensi P, Rahelic D, Ceriello A. Report from the 2nd Cardiovascular Outcome Trial (CVOT) Summit of the Diabetes and Cardiovascular Disease (D\&CVD) EASD Study Group. Cardiovasc Diabetol. 2017;16(1):35.

37. Schnell O, Standl E, Catrinoiu D, Genovese S, Lalic N, Skra J, Valensi P, Ceriello A. Report from the 1st Cardiovascular Outcome Trial (CVOT) summit of the diabetes \& cardiovascular disease (D\&CVD) EASD Study Group. Cardiovasc Diabetol. 2016;15:33.

38. Cosentino F, Cannon CP, Cherney DZI, Masiukiewicz U, Pratley R, DagogoJack S, Frederich R, Charbonnel B, Mancuso J, Shih WJ, et al. Efficacy of ertugliflozin on heart failure-related events in patients with type 2 diabetes mellitus and established atherosclerotic cardiovascular disease: results of the VERTIS CV trial. Circulation. 2020;142(23):2205-15.

39. Anker SD, Butler J, Filippatos G, Khan MS, Marx N, Lam CSP, Schnaidt S, Ofstad AP, Brueckmann M, Jamal W, et al. Effect of empagliflozin on cardiovascular and renal outcomes in patients with heart failure by baseline diabetes status - results from the EMPEROR-reduced trial. Circulation. 2020;143(4):337-49.

40. Zannad F, Ferreira JP, Pocock SJ, Anker SD, Butler J, Filippatos G, Brueckmann M, Ofstad AP, Pfarr E, Jamal W, et al. SGLT2 inhibitors in patients with heart failure with reduced ejection fraction: a meta-analysis of the EMPEROR-Reduced and DAPA-HF trials. Lancet. 2020;396(10254):819-29.

41. Liu LC, Schutte E, Gansevoort RT, van der Meer P, Voors AA. Finerenone : third-generation mineralocorticoid receptor antagonist for the treatment of heart failure and diabetic kidney disease. Expert Opin Investig Drugs. 2015;24(8):1123-35

42. Kolkhof P, Jaisser F, Kim SY, Filippatos G, Nowack C, Pitt B. Steroidal and novel non-steroidal mineralocorticoid receptor antagonists in heart failure and cardiorenal diseases: comparison at bench and bedside. Handb Exp Pharmacol. 2017;243:271-305.

43. Das SR, Everett BM, Birtcher KK, Brown JM, Cefalu WT, Januzzi JL Jr, Kalyani RR, Kosiborod M, Magwire ML, Morris PB, et al. 2018 ACC expert consensus decision pathway on novel therapies for cardiovascular risk reduction in patients with type 2 diabetes and atherosclerotic cardiovascular disease: a report of the American College of Cardiology Task Force on Expert Consensus Decision Pathways. J Am Coll Cardiol. 2018;72(24):3200-23.

44. Buse JB, Wexler DJ, Tsapas A, Rossing P, Mingrone G, Mathieu C, D'Alessio DA, Davies MJ. 2019 update to: Management of hyperglycaemia in type 2 diabetes, 2018. A consensus report by the American Diabetes Association (ADA) and the European Association for the Study of Diabetes (EASD). Diabetologia. 2020;63(2):221-8.

45. Buse JB, Wexler DJ, Tsapas A, Rossing P, Mingrone G, Mathieu C, D'Alessio DA, Davies MJ. 2019 update to: management of hyperglycemia in type 2 diabetes, 2018. A Consensus Report by the American Diabetes Association (ADA) and the European Association for the Study of Diabetes (EASD). Diabetes Care. 2019;43(2):487-93.

46. McGuire DK, Shih WJ, Cosentino F, Charbonnel B, Cherney DZI, Dagogo-Jack S, Pratley R, Greenberg M, Wang S, Huyck S, et al. Association of SGLT2 inhibitors with cardiovascular and kidney outcomes in patients with type 2 diabetes: a meta-analysis. JAMA Cardiol. 2020. https://doi.org/10.1001/jamacardio.2020.4511.

47. Heerspink HJL, Parving HH, Andress DL, Bakris G, Correa-Rotter R, Hou FF, Kitzman DW, Kohan D, Makino H, McMurray JJV, et al. Atrasentan and renal events in patients with type 2 diabetes and chronic kidney disease (SONAR): a double-blind, randomised, placebo-controlled trial. Lancet. 2019;393(10184):1937-47.

48. Niewczas MA, Pavkov ME, Skupien J, Smiles A, Md Dom ZI, Wilson JM, Park J, Nair V, Schlafly A, Saulnier PJ, et al. A signature of circulating inflammatory proteins and development of end-stage renal disease in diabetes. Nat Med. 2019;25(5):805-13.

49. Mora-Fernández C, Domínguez-Pimentel V, de Fuentes MM, Górriz UL, Martínez-Castelao A, Navarro-González JF. Diabetic kidney disease: from physiology to therapeutics. J Physiol. 2014;592(18):3997-4012.

50. Bauersachs J, Jaisser F, Toto R. Mineralocorticoid receptor activation and mineralocorticoid receptor antagonist treatment in cardiac and renal diseases. Hypertension. 2015;65(2):257-63. 
51. Kristensen SL, Rorth R, Jhund PS, Docherty KF, Sattar N, Preiss D, Kober L, Petrie MC, MCMurray JJV. Cardiovascular, mortality, and kidney outcomes with GLP-1 receptor agonists in patients with type 2 diabetes: a systematic review and meta-analysis of cardiovascular outcome trials. Lancet Diabetes Endocrinol. 2019;7(10):776-85.

52. Bethel MA, Patel RA, Merrill P, Lokhnygina Y, Buse JB, Mentz RJ, Pagidipati NJ, Chan JC, Gustavson SM, Iqbal N, et al. Cardiovascular outcomes with glucagon-like peptide-1 receptor agonists in patients with type 2 diabetes: a meta-analysis. Lancet Diabetes Endocrinol. 2018;6(2):105-13.

53. Zelniker TA, Wiviott SD, Raz I, Im K, Goodrich EL, Furtado RHM, Bonaca MP, Mosenzon O, Kato ET, Cahn A, et al. Comparison of the effects of glucagonlike peptide receptor agonists and sodium-glucose cotransporter 2 inhibitors for prevention of major adverse cardiovascular and renal outcomes in type 2 diabetes mellitus. Circulation. 2019;139(17):2022-31.

54. WHO coronavirus disease (COVID-19) dashboard. [https://covid19.who.int/. Accessed 29 Oct 2020

55. Wu Z, McGoogan JM. Characteristics of and important lessons from the coronavirus disease 2019 (COVID-19) outbreak in China: summary of a report of 72314 cases from the Chinese center for disease control and prevention. JAMA. 2020;323(13):1239-42.

56. Ceriello A, Standl E, Catrinoiu D, Itzhak B, Lalic NM, Rahelic D, Schnell O, Škrha J, Valensi P. Issues of cardiovascular risk management in people with diabetes in the COVID-19 Era. Diabetes Care. 2020;19:dc200941.

57. Guzik TJ, Mohiddin SA, Dimarco A, Patel V, Savvatis K, Marelli-Berg FM, Madhur MS, Tomaszewski M, Maffia P, D'Acquisto F, et al. COVID-19 and the cardiovascular system: implications for risk assessment, diagnosis, and treatment options. Cardiovasc Res. 2020;116(10):1666-87.

58. Ceriello A, Standl E, Catrinoiu D, Itzhak B, Lalic NM, Rahelic D, Schnell O, Škrha J,Valensi P. Issues for the management of people with diabetes and COVID-19 in ICU. Cardiovasc Diabetol. 2020;19(1):114.

59. Varga Z, Flammer AJ, Steiger P, Haberecker $M$, Andermatt R, Zinkernagel AS, Mehra MR, Schuepbach RA, Ruschitzka F, Moch H. Endothelial cell infection and endotheliitis in COVID-19. Lancet. 2020;395(10234):1417-8.

60. Channappanavar R, Perlman S. Pathogenic human coronavirus infections: causes and consequences of cytokine storm and immunopathology. Semin Immunopathol. 2017;39(5):529-39.

61. Huang C, Wang Y, Li X, Ren L, Zhao J, Hu Y, Zhang L, Fan G, Xu J, Gu X, et al. Clinical features of patients infected with 2019 novel coronavirus in Wuhan, China. Lancet. 2020;395(10223):497-506.

62. Seidu S, Cos X, Brunton S, Harris SB, Jansson SPO, Mata-Cases M, Neijens AMJ, Topsever P, Khunti K. A disease state approach to the pharmacological management of Type 2 diabetes in primary care: a position statement by Primary Care Diabetes Europe. Prim Care Diabetes. 2020;15(1):31-51.

63. Cos X, Seidu S, Brunton S, Harris SB, Jansson SPO, Mata-Cases M, Neijens AMJ, Topsever P, Khunti K. Impact on guidelines: The general practitioner point of view. Diabetes Res Clin Pract. 2020;166:108091.

64. Inzucchi SE, Bergenstal RM, Buse JB, Diamant M, Ferrannini E, Nauck M, Peters AL, Tsapas A, Wender R, Matthews DR. Management of hyperglycemia in type 2 diabetes, 2015: a patient-centered approach: update to a position statement of the American Diabetes Association and the European Association for the Study of Diabetes. Diabetes Care. 2015;38(1):140-9.

65. Cosentino F, Grant PJ, Aboyans V, Bailey CJ, Ceriello A, Delgado V, Federici M, Filippatos G, Grobbee DE, Hansen TB, et al. 2019 ESC Guidelines on diabetes, pre-diabetes, and cardiovascular diseases developed in collaboration with the EASD. Eur Heart J. 2020;41 (2):255-323.

66. American Diabetes Association. 2. classification and diagnosis of diabetes. Diabetes Care. 2018;41(Supplement 1):S13-27.

67. Gerstein HC, Colhoun HM, Dagenais GR, Diaz R, Lakshmanan M, Pais P, Probstfield J, Botros FT, Riddle MC, Ryden L, et al. Dulaglutide and renal outcomes in type 2 diabetes: an exploratory analysis of the REWIND randomised, placebo-controlled trial. Lancet. 2019;394(10193):131-8.

68. Kristensen SL, Rørth R, Jhund PS, Docherty KF, Sattar N, Preiss D, Køber L, Petrie MC, McMurray JJV. Cardiovascular, mortality, and kidney outcomes with GLP-1 receptor agonists in patients with type 2 diabetes: a systematic review and meta-analysis of cardiovascular outcome trials. Lancet Diabetes Endocrinol. 2019;7(10):776-85.

69. Elliott JH, Synnot A, Turner T, Simmonds M, AkI EA, McDonald S, Salanti G, Meerpohl J, MacLehose H, Hilton J, et al. Living systematic review:
1. Introduction-the why, what, when, and how. J Clin Epidemiol. 2017;91:23-30.

70. AkI EA, Meerpohl J, Elliott J, Kahale LA, Schünemann HJ. Living systematic reviews: 4 Living guideline recommendations. J Clin Epidemiol. 2017;91:47-53.

71. Trends in adult body-mass index in 200 countries from 1975 to 2014: a pooled analysis of 1698 population-based measurement studies with 19\&\#xb7;2 million participants. Lancet 2016, 387(10026):1377-1396.

72. Blüher M. Obesity: global epidemiology and pathogenesis. Nat Rev Endocrinol. 2019;15(5):288-98.

73. Garg SKL, Whitaker M, et al. Hospitalization rates and characteristics of patients hospitalized with laboratory-confirmed coronavirus disease 2019-COVID-NET, 14 States, March 1-30, 2020. MMWR Morb Mortal Wkly Rep. 2020;69:458-64.

74. Huang Y, Lu Y, Huang YM, Wang M, Ling W, Sui Y, Zhao HL. Obesity in patients with COVID-19: a systematic review and meta-analysis. Metabolism. 2020;113:154378.

75. Chang SH, Stoll CR, Song J,Varela JE, Eagon CJ, Colditz GA. The effectiveness and risks of bariatric surgery: an updated systematic review and metaanalysis, 2003-2012. JAMA Surg. 2014;149(3):275-87.

76. Lean ME, Leslie WS, Barnes AC, Brosnahan N, Thom G, McCombie L, Peters C, Zhyzhneuskaya S, Al-Mrabeh A, Hollingsworth KG, et al. Primary care-led weight management for remission of type 2 diabetes (DiRECT): an openlabel, cluster-randomised trial. Lancet. 2018;391(10120):541-51.

77. Jain SS, Ramanand SJ, Ramanand JB, Akat PB, Patwardhan MH, Joshi SR. Evaluation of efficacy and safety of orlistat in obese patients. Indian J Endocr Metab. 2011;15(2):99-104.

78. le Roux CW, Astrup A, Fujioka K, Greenway F, Lau DCW, Van Gaal L, Ortiz RV, Wilding JPH, Skjøth TV, Manning LS, et al. 3 years of liraglutide versus placebo for type 2 diabetes risk reduction and weight management in individuals with prediabetes: a randomised, double-blind trial. Lancet. 2017;389(10077):1399-409.

79. Verpeut UL, Bello NT. Drug safety evaluation of naltrexone/bupropion for the treatment of obesity. Expert Opin Drug Saf. 2014;13(6):831-41.

80. Kushner RF, Calanna S, Davies M, Dicker D, Garvey WT, Goldman B, Lingvay I, Thomsen M, Wadden TA, Wharton S, et al. Semaglutide $2.4 \mathrm{mg}$ for the treatment of obesity: key elements of the STEP trials 1 to 5. Obesity. 2020;28(6):1050-61.

81. Vaduganathan M, Patel RB, Singh A, McCarthy CP, Qamar A, Januzzi JL Jr, Scirica BM, Butler J, Cannon CP, Bhatt DL. Prescription of glucagonlike peptide-1 receptor agonists by cardiologists. J Am Coll Cardiol. 2019;73(12):1596-8.

82. Hansen D, Mellbin L, Cosentino F, De Bacquer D, Grobbee D, Van Ryckeghem L, Standl E, Beulens JW. High awareness of diabetes as a key cardiovascular risk factor among healthcare professionals but suboptimal treatment: results from a survey of the European Association of Preventive Cardiology. Eur J Prev Cardiol. 2020. https://doi.org/10.1177/2047487320911845.

\section{Publisher's Note}

Springer Nature remains neutral with regard to jurisdictional claims in published maps and institutional affiliations. 